\title{
DAMPAK GLOBALISASI PASAR DAN PRODUKSI: DITENGAH LINGKUNGAN BISNIS NASIONAL
}

\author{
A.A.G Agung Artha Kusuma ${ }^{(1)}$ \\ KM Agus Satria Pramudana ${ }^{(2)}$ \\ ${ }^{1,2}$ Fakultas Ekonomi dan Bisnis, Universitas Udayana, Bali, Indonesia \\ email : arthak1007@gmail.com
}

\begin{abstract}
ABSTRAK
Studi ini mendalami bagaimana konsumen mengevaluasi produk dengan membedakan asal merk dengan lokasi produksi akibat dari adanya multiple country of origin. pertama, studi ini menguji pengaruh citra kuat signal dari produk fashion, ditunjukan bahwa, persepsi kualitas, kesadaran merk, dan kesadaran fashion memiliki hubungan yang kuat terhadap kemauan membeli. Analisa kedua, elemen citra negara yang lemah, dipasangkan dengan ethnocentrism tidak memiliki pengaruh moderasi terhadap hubungan kesadaran merk, persepsi kualitas, kesadaran fashion kepada kemauan membeli, selanjutnya studi ini menganalisa bagaimana interaksi antara citra negara dan citra merk mempengaruhi keputusan pembelian. Proses analisis data menggunakan regresi PLS, dengan total responden 173 orang. Hasil analisis menghasilkan kesimpulan bahwa dalam mengaveluasi produk fashion, kekuatan citra merk lebih berpengaruh dibandingkan citra negara produk fashion itu diproduksi terhadap kemauan membeli, sedangkan untuk sikap ethnocentric konsumen, terbukti tidak mampu memiliki peran terhadap pengaruhnya kepada globalisasi pasar dan produksi, dimana pada studi ini diterjemahkan dengan variabel country of origin.
\end{abstract}

Kata kunci: pemasaran internasional, pemasaran lintas budaya, country of origin, consumer ethnocentrism.

\begin{abstract}
This study explores how consumer evaluates a product by discriminating the difference between the brand and manufacturing origin. First is analysed the impact of strong image that presents with fashion products toward purchase intention, the test concludes that perceived quality, brand awareness, and fashion involvement has positive correlation toward purchase intention. Further analysed the weak country image concept in moderating function, the test summarized that country of origin and consumer ethnocentrism cannot influence the relationship of brand awareness, perceived quality, and fashion involvement toward purchase intention. Further in this study is discussed the interaction between country's image and brand image affecting purchase intention. Data analysis is using PLS regression, with total recipients of 173. In summary, in evaluating fashion products, the decisive factor in affecting purchase intention is the image conveyed from the brand, with the two aspect of globalization is translated through variable of country of origin.
\end{abstract}

Keywords: international marketing, cross-cultural marketing, country of origin, consumer ethnocentrism

\section{PENDAHULUAN}

Globalisasi mempresentasikan tantangan dan peluang kepada pemasar internasional. Semakin terintegrasinya Negara-negara secara regional membentuk trading bloc, mendorong volume perdagangan dan investasi internasional, memberikan konsumen pilihan akan produk asing semakin banyak dari sebelumnya. Akibatnya, sikap dan perilaku konsumen terhadap produk yang berasal dari Negara asing telah menjadi tema pilihan studi-studi di bidang bisnis internasional dan perilaku konsumen beberapa tahun belakangan ini (C. L. Wang \& Chen, 2004), terlebih pada lingkup pemasaran global, dampak country of origin terhadap pilihan konsumen merupakan topik studi yang secara intesif dikembangkan dan berhasil mengidentifikasi berbagai kontingensi dan serangkain moderator dari country of origin (Thøgersen et al., 2017).

Dengan terakselerasinya globalisasi, konsumen didunia dihadapkan dengan besarnya jumlah merk, baik asing atau domestik. Perusahaan multi nasional telah mengembangkan berbagai merk global dari industri makanan dan minuman (McDonald, Starbucks, Cadbury) hingga industri fashion (Guess, Adidas, Mark \& Spencer). Merk-merk dari perusahan multi nasional telah dikenal dengan baik oleh konsumen di seluruh dunia, memiliki identitas yang mapan, dan dipersepsikan merepresentasikan status dan kualitas yang tinggi (Anholt, 2005). Karena adanya asosiasi positif tersebut, merk-merk global memiliki kekuatan diferensiasi di berbagai pasar internasional, dimana konsumen lebih ingin meningkatkan harga diri dan kompetensi dengan 
mengadopsi merk yang terlihat modern dan kosmopolitan (Alden, Steenkamp, \& Batra, 1999). Fenomena ini dapat dipengaruhi oleh citra negara dimana produk tersebut diproduksi (Cattin, Jolibert, \& Colleen, 1982; Lumpkin, Crawford, \& Kim, 1985; Roth \& Romeo, 1992). Dihasilkan oleh Negara tertentu dapat memberikan persepsi negatif atau positif di benak konsumen (Ghauri \& Cateora, 2014), perusahaan multi nasional yang menghasilkan merk dan produk global harus menyadari bahwa dalam pasar global tetap didalamnya terdapat elemen lingkungan nasional yang berisikan budaya lokal masyarakat setempat. Budaya lokal yang tetap melekat pada kelompok-kelompok masyarakat merupakan benih perilaku ethnocentric (Torelli, 2013), sikap yang cenderung memandang budaya sendiri lebih superior dibanding budaya asing. Ironisnya consumer ethnocentrism justru menjadi senjata strategis bagi merk dan produk lokal untuk tetap kompetitif dalam menghadapi persaingan global. Ditengah tumbuhnya perekonomian negara industri baru dan nNegara berkembang, begitu juga nilai-nilai materialistik masyarakatnya, dibantu dengan majunya industri keuangan untuk memperbesar konsumsi melalui pembelanjaan kredit (Thomas \& Wilson, 2013) secara langsung akan mempengaruhi perilaku materialisme yang kian berorientasi kepada budaya asing.

Jelas salah satu isu paling kontroversial yang terkait dengan globalisasi adalah bagaimana dampaknya terhadap budaya (Holton, 2000), sejumlah studi memaparkan dampak positif globalisasi terhadap budaya lokal (Bhagwati, 2007) di sisi lain studi sejenis menyatakan bahwa globalisasi justru akan menghancurkan keragaman budaya lokal, dengan menekankan pengaruh asing (van Elteren, 2014). Seiring meluasnya globalisasi terjadi peningkatan juga pada sikap nasionalisme dan pelestarian budaya untuk identitas etnis oleh masyarakat (Kucukemiroglu, 1999), consumer ethnocentrism adalah kekuatan yang penting dalam lingkungan bisnis global untuk dimasa mendatang, oleh karena itu dengan memahami peran kultur terahadap perluasan globalisasi akan memberikan manfaat kepada ilmu pemasaran dalam pengembangan strategi global (standarisasi) yang bersinergi harmonis kepada budaya lokal target pasar.

Berdasarkan uraian diatas, jelas terdapat ruang pada pada area pemasaran internasional yang mendorong munculnya pertanyaan dimana persepsi country of origin menjadi relatif terhadap citra negara terhadap konsumen namun dengan adanya kombinasi citra merk dan citra negara maka ditambah dengan sikap ethnocentric konsumen maka studi ini bertujuan memberikan kontribusi kepada ilmu pengetahuan khususnya di area country of origin dan consumer ethnocentrism, penelitian ini mengarah kepada pendalaman bagaimana peran citra yang kuat bersumber dari merk, persepsi kualitas, dan keterlibatan akan fashion terhadap kemauan membeli, sedangkan citra negara yang lemah dan sikap terhadap penjagaan kelestarian budaya lokal akan menggunakan konsep country of origin dan consumer ethnocentrism yang akan berperan sebagai moderator.

Lebih dari tiga dekade terakhir, berbagai literatur pemasaran menekankan pentingnya persepsi yang dibentuk oleh merk, beserta komponen-komponen pembentuknya. (De Chernatony, McDonald, \& Wallace, 2010; Feldwick, 1996) Telah menyatakan terdapat enam jenis atribut merk yang membentuk brand equity: kesadaran merk, citra merk, persepsi kualitas, persepsi nilai, personalitas, dan asosiasi terhadap organisasi. Bersamaan juga telah didokumentasikan bahwa persepsi konsumen terhadap merk belumlah cukup untuk menentukan kesuskesan merk dengan kata lain belum cukup alasan bagi konsumen untuk melakukan pembelian. Yang menjadi penentu keberhasilan merk di pasar adalah merk harus mampu menawarkan nilai superior dan pembeda dibandingkan kompetitor (Kim, Ferrin, \& Rao, 2008).

Persepsi nilai superior adalah suatu keunggulan yang dimiliki merk global (perushaan multinasional) terutama di pasar berkembang (Chiu \& Ho, 2015), situasi inilah yang menjadi keunggulan kompetitif merk global diberbagai pasar domestik (Alden et al., 1999). Memanfaatkan keunggulan yang dimiliki merk global, perusahaan multinasional juga akhirnya mampu menerapkan strategi harga yang lebih fleksibel (H. Wang, Wei, \& Yu, 2008), dalam artian mensetting harga cukup tinggi untuk memberikan persepsi premium, namun cukup terjangkau bagi konsumen di pasar berkembang (Boguslaw, 2015). Berdasarkan hasil-hasil penelitian yang telah dipaparkan maka hipotesis yang dapat dibentuk untuk penelitian ini adalah:

H1: Kesadaran merk berpengaruh positif terhadap kemauan membeli.

Persepsi akan kualitas adalah komponen inti terhadap brand equity berbasis konsumen. Persepsi kualitas menggabungkan segala manfaat dan atribut yang terbentuk di benak konsumen, dari fungsi dasar produk (utility), performa, hingga usia kegunaan produk yang dimaksud (Chiu \& Ho, 2015). Berbagai 
studi menunjukan bahwa persepsi kualitas sangat esensial kepada brand equity karena dapat menambahkan nilai terhadap produk (Çifci et al., 2016) yang berkelanjutan kepada kemampuan perusahaan untuk menetapkan harga relatif lebih tinggi dibandingkan kompetitor.

Harga merupakan salah satu alat strategis bagi pemasar sebagai pemberi signal yang menununjuk akan suatu kualitas atau manfaat, harga lebih tinggi biasa diasosiasikan dengan kualitas lebih baik (González-Benito \& Martos-Partal, 2014). Dengan adanya persepsi akan kualitas pada benak konsumen, dengan sendirinya suatu merk akan terdiferensiasi diantaran merk-merk pesaing, sehingga akan memberikan alasan kepada konsumen untuk melakukan pembelian (Pappu, Quester, \& Cooksey, 2005). Berdasarkan pemaparan hasil-hasil studi diatas maka dapat dibangun hipotesis untuk penelitian ini adalah:

H2: Persepsi kualitas berpengaruh positif terhadap kemauan membeli.

Dalam masyarakat yang berorientasi materi, konsumen akan menilai suatu kepemilikian barangbarang bersifat materialistik, salah satunya yang paling meningkat konsumsinya pada masyarakat negara berkembang, disertai dengan pertumbuhan aktivitas pembentukan citra diri melalui sosial media adalah produk fashion (Kamal, Chu, \& Pedram, 2013). Aspek penting dalam kepemilikan benda materialistik diantaranya manfaat, penampilan, nilai finasial, dan kemampuan mencerminkan status, sukses, dan prestise (O'Cass, 2000). Pakaian sering digunakan untuk mengekspresikan diri seseorang, terutama untuk menunjukan status diri dan kesuksesan (Richins \& Dawson, 1992), terdapat banyak studi yang mengkaitkan interaksi antara sikap materialistik, merk, serta kesadaran akan fashion, dan menemukan kesimpulan bahwa sikap materialistik berpengaruh positif terhadap keterlibatan akan penampilan (Goldsmith, Flynn, \& Clark, 2012; Johnson \& Attmann, 2009).

Berkaitan dengan sikap materialistik dan keterlibatan akan fasion berbagai hasil studi menyatakan individu yang memiliki keterlibatan fashion yang tinggi akan cenderung memiliki perilaku pembelian impulsive (Joung, 2013), studistudi tersebut juga berkesimpulan bahwa konsumen yang memiliki kesadaran fashion tinggi akan melakukan pembelian fashion lebih awal, bahkan merekomendasikan produk fashion kepada relasi mereka (Belleau, Haney, Summers, Xu, \& Garrison,
2008). Berdasarkan uraian dari hasil riset-riset diatas maka dapat dikembangkan hipotesis untuk penelitian ini adalah:

H3: Kesadaran fashion berpengaruh positif terhadap kemauan membeli.

Country of origin sebuah produk telah didefinisikan sebagai negara yang memanufaktur atau merakit (Warren J. Bilkey, 1982), diidentifikasi dengan menggunakan label "made in" atau "manufactured in" (Nagashima, 1977). Akan tetapi dengan tumbuhnya perusahaan multinasional dan berkembangnya globalisasi produksi maka terciptalah produk hybrid dimana suatu produk yang komponennya bersumber dari berbagai Negara telah mengaburkan akurasi atau validitas label "made in" atau "manufactured in" (Z. U. Ahmed et al., 2004), sehinggga dalam mengidentifikasi country of origin terkadang sangat sulit. Ketika situasi ini dihadapi konsumen, maka dalam proses keputusan pembelian, terutama pada pasar berkembang, pembeli potensial akan mengkombinasikan petunjukpetunjuk yang berasal dari merk, harga, dan citra Negara asal, sehingga terjadi kecenderungan menganggap produk impor yang berasal dari Negara maju adalah superior dalam hal kualitas (citra negara), sedangkan produk dari sesama pasar berkembang adalah produk yang memiliki kualitas setara atau bahkan inferior dibandingkan produk domestik mereka (Hu, Li, Xie, \& Zhou, 2008; Kinra, 2006; X. Wang \& Yang, 2008). Walaupun suatu merk dikatakan memiliki dampak langsung yang positif terhadap kemauan membeli, aspek lain yang relatif penting terhadap merk bisa juga diakibatkan oleh citra country of origin (Rashid, 2016). Banyak studi ilmiah juga menyatakan kombinasi citra Negara penghasil dan citra merk berdampak kuat kepada pembelian (Hsieh et al., 2004).

Merk dan citra Negara juga mempengaruhi dimensi evaluasi kualitas oleh konsumen (Touzani, Fatma, \& Meriem, 2015), juga dijelaskan citra Negara adalah petunjuk yang berdampak kepada persepsi kualitas, baik secara langsung atau tidak langsung melalui brand equity. Maka ketika suatu merk bisa dengan jelas dibedakan dengan merk lainnya, dan citra country of origin dipersepsikan positif, maka konsumen akan memiliki perspesi keyakinan yang tinggi terhadap suatu merk tersebut, sehingga akan lebih mudah dipengaruhi oleh merk dalam hal kemauan membeli. Sebaliknya ketika suatu brand equity dipersepsikan positif tetapi citra country of origin dipersepsikan negatif maka 
hubungan kedua variabel tersebut akan menjadi lemah, dan merk akan kurang berpengaruh terhadap kemauan membeli (X. Wang \& Yang, 2008).

Berdasarkan hasil riset sebelumnya, citra positif country of origin dapat memperkuat dampak kekuatan merk terhadap kemauan membeli, sedangkan citra country of origin yang negatif akan memperlemah dampak kekuatan merk terhadap kemauan membeli (X. Wang \& Yang, 2008). Kesimpulannya tidak hanya merk yang kuat berdampak positif kepada kemauan membeli, tetapi jika didukung oleh citra Negara yang positif akan semakin memperkuat dorongan kemauan membeli. Dengan rasional seperti yang telah diuraikan maka hipotesis yang dapat dibangun untuk penelitian ini adalah:

H4: Pengaruh kesadaran merk, persepsi kualitas, dan kesadaran fashion terhadap kemauan membeli, dimoderasi oleh country of origin

Pembahasan literatur mengungkapkan bahwa consumer ethnocentrism memiliki pengaruh besar terhadap persepsi konsumen mengenai produk yang dibuat atau dihasilkan dinegara lain. (Shimp \& Sharma, 1987) menyimpulkan konstruk consumer ethnocentrism dengan mendesain CETSCALE, sebuah skala ukur dengan menggunakan tujuh belas item. Diajukan oleh (P. Sharma, 2015) istilah consumer ethnocentrism didefinisikan sebagai "keyakinan yang dipegang oleh konsumen mengenai hal kepantasan, moralitas, dalam pembelian produk buatan asing". Esensi dari konstruk tersebut menyatakan perilaku membeli produk buatan asing adalah sikap tidak patriotik karena dapat menyakiti ekonomi domestik dan menyebabkan hilangnya pekerjaan. Consumer ethnocentrism juga menambahkan bahwa individu-individu akan melakukan sesuatu untuk membuat perbedaan kepada identitas nasionalnya dari indetitas nasional Negara lain, sehingga secara umum digambarkan dengan isitilah orientasi in-group/out-group (Shimp \& Sharma, 1987). Riset-riset terdahulu telah mendokumentasikan semakin menguatnya daya tarik mer-merk global (brand conscious) pada beberapa segmen pasar, terutama kepada remaja (Lysonski, 2014).

Dalam pemikiran yang berfokus kepada ekonomi nasional dan kesejahteraan pribadi, merk global bisa dipandang sebagai pengancam kesejahteraan ekonomi nasional (E M Steenkamp, Batra, \& Alden, 2003), terlebih dalam benak konsumen yang ethnocentric meluasnya pengaruh perusahaan multinasional beserta merk global terhadap sistem ekonomi dan politik Negara dapat mengikis budaya lokal setempat. Semakin rendah tingkat kosmopolitan dan keterbukaan terhadap budaya asing semakin berkontribusi kepada evaluasi negatif suatu merk global oleh konsumen ethnocentric (E M Steenkamp et al., 2003). Konsumen dengan rasa ethnocentric tinggi bahkan bersedia untuk mengorbankan perolehan objektif (kualitas lebih tinggi, harga lebih murah, prestise) demi menikmati manfaat psikologis untuk terhindar dari kontak dengan outgroup (global culture) dengan cara mengkonsumsi merk lokal (Baughn \& Yaprak, 1996). Pada sisi yang berlawanan, konsumen dengan rasa ethnocentric rendah memiliki karakteristik cosmopolitan, serta keterbukaan yang tinggi kepada kultur asing (Baughn \& Yaprak, 1996), mereka tidak menganggap merk lokal berperan penting terhadap ekonomi nasional dan kesejahteraan pribadi, justru konsumen ini lebih merasakan manfaat psikologis dengan memiliki kontak dengan kultur asing yang diwakili merk global (E M Steenkamp et al., 2003).

Berdasarkan kerangka penelitian studi ini, sangat logis jika diasumsikan aplikasi ethnocentric pada konsumen memiliki tingkat dan kekuatan yang bervariasi, berdasarkan pandangan tersebut maka hipotesis yang dapat dikembangkan adalah:

H5: Pengaruh kesadaran merk, persepsi kualitas, dan kesadaran fashion terhadap kemauan membeli, dimoderasi oleh consumer ethnocentrism.

\section{METODE PENELITIAN Desain Penelitian}

Berdasarkan ulasan literatur yang telah diuraikan sebelumnya, maka studi ini mengajukan model yang merepresentasikan hubungan yang teridentifikasi menjadi variabel penelitian ini (Gambar 1).

Untuk mengimplementasikan studi ini maka beberapa merk fashion global, penetrasi pasar yang luas, dan proses produksinya di negara berkembang dipilih, diantaranya Adidas, Nike, Topshop, Zara, H\&M, Gap, dan beberapa merk fashion lainnya. Alasan produk fashion global dipilih dengan rasional bahwa jenis produk fashion adalah high involvement product sehingga informasi yang berkaitan asal produknya tidak bisa dihindari, brand tersebut memiliki citra kuat yang berasal dari negara dengan kultur fashion tinggi, sedangkan proses produksi dilakukan pada negara dengan citra yang lemah, kombinasi ini memberikan konflik yang menarik untuk memahami lebih dalam proses evaluasi produk bagi konsumen yang berkaitan 


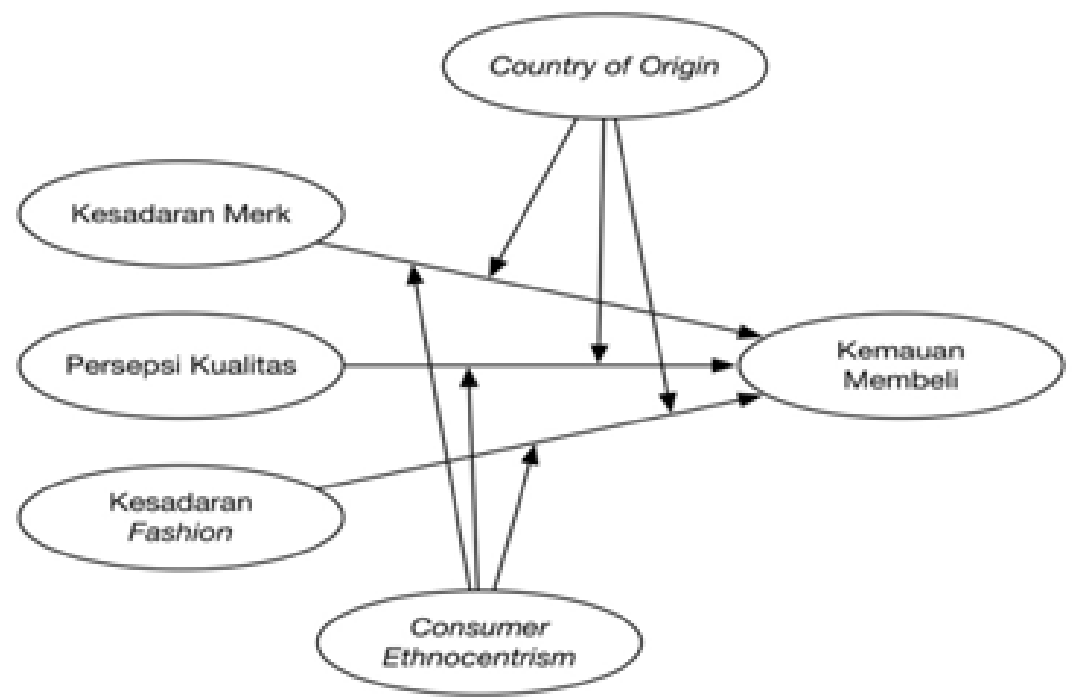

Gambar 1: Desain Penelitian

dengan budaya, kekuatan merk, dan kemauan membeli.

\section{Kuesioner dan Skala Pengukuran}

Desain kuesioner pada studi ini mengadaptasi dari studi-studi terdahulu utamanya pada area country of origin dan consumer ethnocentrism (S. A. Ahmed, d'Astous, \& Champagne, 2005; S. Sharma, Shimp, \& Shin, 1995). Secara keseluruhan instrumen penelitian terbagi atas empat bagian dengan tiap-tiap indikator diukur menggunakan skala Likert lima poin yang terdefinisi: (1) Sangat tidak setuju, (2) Tidak setuju, (3) Netral, (4) Setuju, (5) Sangat setuju. Aspek pertama, mencangkup kesadaran merk dan persepsi kualitas adalah dua variabel yang ditujukan untuk mengukur kekuatan citra dari fashion global, kedua, kesadaran fashion merupakan variabel yang digunakan untuk mengukur sikap materialisme konsumen yang umum digunakan pada studi konsumen negara berkembang seperti Indonesia, ketiga, country of origin dan consumer ethnocentrism adalah dua variabel moderasi yang bertujuan mengukur peran sikap konsumen yang berkaitan dengan negara dan budaya dalam menentukan kemauan membeli, bagian tambahan pada instrumen adalah pertanyaan-pertanyaan yang mendeskripsikan demografi konsumen.

\section{Gambaran Umum Globalisasi Ritel Fashion}

Sebagaimana citra fashion yang umumnya tampak pada majalah, video musik, film, penyebaran adaptasinya terakselerasi oleh internet dan televisi mendorong suatu trend fashion keseluruh dunia, hingga menciptakan 'global style' yang melintasi batasan budaya dan bangsa. Berbagai jenis item pakaian (jeans, kaos, sepatu, jacket, topi) memiliki nuansa gaya yang seragam hampir diseluruh pelosok dunia. Antar benua saling bertukar bahan dan sumber produksi pada industri textile, selanjutnya shopping malls pada kota-kota besar menghimpun produk-produk fashion ini dibawah satu atap, menawarkan kepada konsumen pada setiap umur, segala jenis kelamin, semua etnis, hingga keseluruh profesi dan sub-kultur.

Kecenderungan ini akan menyebabkan pasarpasar pada berbagai lokasi mengalami proses homogenisasi preferensi, sekilas terlihat hampir di semua tempat perbelanjaan menjual produk yang sama, namun jika lebih didalami, produk fashion tersebut memiliki kedalaman variasi yang hampir tidak ada akhirnya. Dalam ilmu pemasaran perilaku yang terkait dengan konsumsi produk fashion diasosiasikan dengan kenikmatan, kekuatan, kepribadian, dan citra diri. Namun pada bidang bisnis ekonomi situasi ini dilihat dari aspek yang berbeda, konsumsi produk fashion bukan suatu yang bersifat pribadi namun adalah dampak dari jaringan antar ekonomi yang saling terikat, menghasilkan output yang sangat besar, dengan input yang berbiaya rendah sehingga terjadi keseimbangan antara konsumsi fashion dalam jumlah besar pada Negara kaya, dan penyerapan tenaga kerja dan kemajuan ekonomi pada Negara miskin.

Produk fashion tidak lagi di produksi oleh perusahaan yang namanya terlihat pada label, pakaian dari ritel global dimanufaktur melalui jaringan kontraktor dan subkontraktor. Perusahaan ritel fashion global meng-outsource kegiatan produksi dan bahan kepada lingkungan ekonomi yang berbiaya rendah, aktivitas ini sering diistilahkan dengan global assembly line. Selanjutnya ritel 
Tabel 1: Matriks Pengembangan Instrumen

\begin{tabular}{|c|c|c|c|}
\hline No & Konsep & Indikator & Referensi \\
\hline \multirow{3}{*}{1} & \multirow{3}{*}{$\begin{array}{l}\text { Kesadaran } \\
\left(\mathrm{X}_{1}\right)\end{array}$} & $\begin{array}{l}\text { Saya familiar dengan merk-merk fashion tersebut } \\
\left(X_{1.1}\right)\end{array}$ & (Jung, Lee, \& Kim, 2014) \\
\hline & & $\begin{array}{l}\text { Saya sadar akan kesan yang dibangun oleh merk-merk } \\
\text { fashion tersebut }\left(\mathrm{X}_{1.2}\right)\end{array}$ & (Jung et al., 2014) \\
\hline & & $\begin{array}{l}\text { Saya dengan mudah mengenali karakteristik merk- } \\
\text { merk fashion tersebut }\left(\mathrm{X}_{1.3}\right)\end{array}$ & $\begin{array}{l}\text { (Yoo, Donthu, \& Lee, } \\
2000)\end{array}$ \\
\hline \multirow{3}{*}{2} & \multirow{3}{*}{$\begin{array}{l}\text { Persepsi } \\
\left(\mathrm{X}_{2}\right)\end{array}$} & $\begin{array}{l}\text { Merk-merk fashion tersebut memiliki kualitas yang } \\
\text { superior dibandingkan merk fashion lainnya }\left(\mathrm{X}_{2.1}\right)\end{array}$ & (Jung et al., 2014) \\
\hline & & $\begin{array}{l}\text { Merk-merk fashion tersebut memiliki kualitas yang } \\
\text { konsisten dibandingkan merk fashion lainnya }\left(\mathrm{X}_{2.2}\right)\end{array}$ & (Jung et al., 2014) \\
\hline & & $\begin{array}{l}\text { Merk-merk fashion tersebut memiliki performa sesuai } \\
\text { harapan saya }\left(\mathrm{X}_{\cdot 2.3}\right)\end{array}$ & $\begin{array}{l}\text { (Dodds, Monroe, } \quad \& \\
\text { Grewal, 1991) }\end{array}$ \\
\hline \multirow{3}{*}{3} & \multirow{3}{*}{$\begin{array}{l}\text { Kesadaran } \\
\text { Fashion }\left(\mathrm{X}_{3}\right)\end{array}$} & $\begin{array}{l}\text { Saya waspada terhadap perubahan trend fashion dari } \\
\text { waktu ke waktu }\left(X_{3.1}\right)\end{array}$ & $\begin{array}{l}\text { (Bakewell, Mitchell, \& } \\
\text { Rothwell, 2006) }\end{array}$ \\
\hline & & $\begin{array}{l}\text { Saya membaca/menonton saluran informasi yang } \\
\text { memuat konten fashion }\left(\mathrm{X}_{3.2}\right)\end{array}$ & (Bakewell et al., 2006) \\
\hline & & $\begin{array}{l}\text { Saya peduli akan pendapat orang lain mengenai } \\
\text { penampilan saya }\left(\mathrm{X}_{3.3}\right)\end{array}$ & (Bakewell et al., 2006) \\
\hline \multirow{3}{*}{4} & \multirow{3}{*}{$\begin{array}{l}\text { Country of Origin } \\
\left(\mathrm{Z}_{1}\right)\end{array}$} & $\begin{array}{l}\text { Produk yang dihasilkan oleh Negara berkembang } \\
\text { (India, China, Bangladesh, Pakistan, Vietnam) secara } \\
\text { umum memiliki kualitas yang sangat baik }\left(\mathrm{Z}_{1.1}\right)\end{array}$ & $\begin{array}{l}\text { (E M Steenkamp et al., } \\
\text { 2003) }\end{array}$ \\
\hline & & $\begin{array}{l}\text { Produk yang dihasilkan oleh Negara berkembang } \\
\text { (India, China, Bangladesh, Pakistan, Vietnam) secara } \\
\text { umum diproduksi dengan level teknologi yang tinggi } \\
\left(\mathrm{Z}_{1.2}\right)\end{array}$ & $\begin{array}{l}\text { (E M Steenkamp et al., } \\
\text { 2003) }\end{array}$ \\
\hline & & $\begin{array}{l}\text { Produk yang dihasilkan oleh Negara berkembang } \\
\text { (India, China, Bangladesh, Pakistan, Vietnam) secara } \\
\text { umum dihasilkan melalui level sistem politik dan } \\
\text { ekonomi yang tinggi }\left(\mathrm{Z}_{1.3}\right)\end{array}$ & (Shirin \& Kambiz, 2011) \\
\hline \multirow{3}{*}{5} & \multirow{3}{*}{$\begin{array}{l}\text { Consumer } \\
\text { Ethnocentrism }\left(\mathrm{Z}_{2}\right)\end{array}$} & $\begin{array}{l}\text { Konsumen Indones ia idealnya membeli produk buatan } \\
\text { Indonesia }\left(\mathrm{Z}_{2.1}\right)\end{array}$ & (Bawa, 2004) \\
\hline & & $\begin{array}{l}\text { Produk yang dihasilkan di luar Negeri idealnya } \\
\text { diberikan pajak yang tinggi untuk membatasi } \\
\text { jumlahnya }\left(\mathrm{Z}_{2.2}\right)\end{array}$ & (Bawa, 2004) \\
\hline & & $\begin{array}{l}\text { Konsumen Indonesia idealnya tidak membeli produk } \\
\text { buatan luar negeri karena akan berdampak pada } \\
\text { peningkatan angka pengangguran }\left(\mathrm{Z}_{2.3}\right)\end{array}$ & (Bawa, 2004) \\
\hline \multirow{3}{*}{6} & \multirow{3}{*}{$\begin{array}{l}\text { Kemauan } \\
\left(\mathrm{Y}_{1}\right)\end{array}$} & $\begin{array}{l}\text { Saya akan membeli (melanjutkan pembelian) jika ada } \\
\left.\text { produk/trend baru dari retail fashion global ( } \mathrm{Y}_{1.1}\right)\end{array}$ & (Chiou \& Chuang, 2005) \\
\hline & & $\begin{array}{l}\text { Membeli (melanjutkan pembelian) dari retail fashion } \\
\text { global seiring dengan trend fashion, bagi saya adalah } \\
\text { keputusan yang baik }\left(\mathrm{Y}_{1.2}\right)\end{array}$ & (Chiou \& Chuang, 2005) \\
\hline & & $\begin{array}{l}\text { Saya akan merekomendasikan produk retail fashion } \\
\text { global kepada keluarga, teman, dan kolega }\left(\mathrm{Y}_{1.3}\right)\end{array}$ & (Boguslaw, 2015) \\
\hline
\end{tabular}

fashion global akan melakukan adaptasi terhadap pasar dan produk untuk kesesuain budaya dan perilaku konsumen setempat.

\section{HASIL DAN PEMBAHASAN Karakteristik Sampel}

Melakukan studi empiris di Indonesia yang berkaitan dengan merk fashion global memiliki tantangan tersendiri, Indonesia merupakan negara dengan populasi yang besar namun dengan komposisi segmentasi konsumen yang sangat heterogen, sehingga untuk memilih sampel yang tepat untuk studi ini merupakan hambatan bagi setiap peneliti. Target populasi dalam penelitian ini adalah seluruh konsumen retail fashion global di Indonesia, sedangkan untuk sampel, konsumen produk fashion global di Bali terpilih karena mewakili kriteria urban dan kosmopolitan, karakteristik ini diperlukan untuk studi ini karena umumnya konsumen memiliki akses terhadap retail fashion global secara luas, memiliki daya beli yang relatif kuat, alternatif produk yang beragam dari produsen dan merk berbeda, dan terekspose akan barbagai macam informasi yang berkaitan dengan gaya hidup. Pengambilan sampel menggunakan metode non-probability sampling dengan tehnik convenience sampling dikarenakan dengan kemudahan akses kepada target populasi (Malhotra, Birks, \& Wills, 2012). Pengumpulan data 
utamanya dilakukan pada lokasi-lokasi perbelanjaan di kawasan Kuta yang didalamnya terdapat gerai ritel fashion global, cara ini diyakini merupakan akses terbaik untuk mencapai target sampel, cara kedua dalam pengumpulan data adalah dengan menyebar kuesioner secara elektronik, target responden adalah individu yang diyakini oleh penulis memenuhi kriteria sebagai sampel dimana sebelumnya telah melalui proses screening (Malhotra, Birks, \& Wills, 2012).

Total kuesioner yang valid untuk dilanjutkan keproses analisa adalah sebanyak 173, berdasarkan informasi pada tabel 2 dapat diringkas bahwa proporsi responden pria dan wanita hampir seimbang, mayoritas responden berusia 18 sampai 24 tahun dengan frekuensi belanja fashion hingga 1-3 kali dalam sebulan, anggaran belanja produk fashion sebesar 56 persen menyatakan dibawah 600 ribu rupiah, hampir seluruh responden menjawab familiar terhadap merk fashion ritel global, 74 persen responden adalah konsumen dari reitel fashion global, masing masing 60 persen dan 32 persen mengetahui asal merk dan asal produksi produk fashion global. Perlu diperhatikan bahwa responden studi ini merupakan individu dengan kemampuan membeli diatas rata-rata penduduk Indonesia secara keseluruhan, hal ini mengingat harga produk ritel fashion global secara umum memang ditujukan kepada konsumen dengan tingkat kemakmuran menengah keatas, sehingga penulis menilai responden studi ini terkualifikasi untuk penelitian kali ini.

Tabel 2: Karakteristik Responden

\begin{tabular}{|c|c|c|c|c|}
\hline No & Variabel & Klasifikasi & Jumlah & Persentase \\
\hline \multirow{3}{*}{1} & \multirow{2}{*}{ Jenis Kelamin } & Pria & 75 & 43.4 \\
\hline & & Wanita & 98 & 56.6 \\
\hline & \multicolumn{2}{|c|}{ Jumlah } & 173 & 100 \\
\hline \multirow{5}{*}{2} & \multirow{4}{*}{ Usia } & $>18-24$ & 125 & 72.3 \\
\hline & & $>24-30$ & 19 & 11 \\
\hline & & $>30-36$ & 27 & 15.6 \\
\hline & & $>36$ & 2 & 1.2 \\
\hline & \multicolumn{2}{|c|}{ Jumlah } & 173 & 100 \\
\hline \multirow{5}{*}{3} & \multirow{4}{*}{$\begin{array}{l}\text { Frekuensi pembelian produk } \\
\text { fashion }\end{array}$} & 1-3 Kali (30) & 84 & 48.6 \\
\hline & & 1-3 Kali (60) & 45 & 26.0 \\
\hline & & 1-3 Kali (90) & 26 & 15.0 \\
\hline & & 1-3 Kali (lebih 90) & 18 & 10.4 \\
\hline & \multicolumn{2}{|c|}{ Jumlah } & 173 & 100 \\
\hline \multirow{5}{*}{4} & \multirow{4}{*}{$\begin{array}{l}\text { Anggaran umum pembelian } \\
\text { produkfashion }\end{array}$} & $<\mathrm{Rp} .600 .000$ & 97 & 56.1 \\
\hline & & >Rp.600.000-Rp.1.200.000 & 58 & 33.5 \\
\hline & & >Rp.1.200.000-Rp.1.800.000 & 12 & 6.9 \\
\hline & & $>$ Rp. 1.800 .000 & 6 & 3.5 \\
\hline & \multicolumn{2}{|c|}{ Jumlah } & 173 & 100 \\
\hline \multirow{3}{*}{5} & \multirow{2}{*}{ Familiaritas } & $\mathrm{Ya}$ & 167 & 96.5 \\
\hline & & Tidak & 6 & 3.5 \\
\hline & \multicolumn{2}{|c|}{ Jumlah } & 173 & 100 \\
\hline \multirow{3}{*}{6} & \multirow{2}{*}{ Konsumen } & $\mathrm{Ya}$ & 128 & 74 \\
\hline & & Tidak & 45 & 26 \\
\hline & \multicolumn{2}{|c|}{ Jumlah } & 173 & 100 \\
\hline \multirow{3}{*}{7} & \multirow{2}{*}{ Negara Asal Merk } & $\mathrm{Ya}$ & 104 & 60.1 \\
\hline & & Tidak & 69 & 39.9 \\
\hline & \multicolumn{2}{|c|}{ Jumlah } & 173 & 100 \\
\hline \multirow{3}{*}{8} & \multirow{3}{*}{ Negara Diproduksi } & $\mathrm{Ya}$ & 116 & 32.9 \\
\hline & & Tidak & 57 & 67.1 \\
\hline & & & 173 & 100 \\
\hline
\end{tabular}

Sumber: Hasil pengolahan data penelitian, 2016

\section{Analisis Data dan Hasil}

Untuk menguji validitas dan reliabilitas instrumen penelitian studi ini menggunakan SPSS 17.0 dimana semua indikator pada setiap variabel memilliki nilai lebih besar dari $r_{\text {tabel }}$ yaitu $0.361\left(r_{\text {hitung }}>r_{\text {tabel }}\right)$, sehingga dapat dinyatakan valid. Untuk uji reliabilitas seluruh variabel penelitian memiliki nilai Cronbach's Alpha diatas 0.60 maka model penelitian ini dinyatakan reliabel sehingga proses analisa dapat dilanjutkan kepada pengujian hipotesis. 


\section{Pengukuran Model Penelitian}

Pada penelitian dengan alat analisis PLS maka dua pendekatan digunakan untuk mengukur validitas model sebelum dilakukan pengujian hipotesis, bertujuan untuk memverifikasi validitas dan reliabilitas model penelitian, pertama dengan menganalisa convergent validity dilanjutkan dengan menganalisa discriminant validity (Barclay, Higgins, \& Thompson, 1995).

\section{Convergent Validity}

Uji convergent validity dilakukan dengan memastikan tiga kriteria harus terpenuhi (Hair Jr, Hult, Ringle, \& Sarstedt, 2016), yaitu (1) indicator loading > 0.5 (2) composite reliability $>0.8$ dan (3) AVE $>0.5$.

Melalui informasi pada Tabel 3 terlihat terdapat nilai cross loading dibawah kriteria yaitu pada

Tabel 3. Pengukuran Convergent Validity

\begin{tabular}{|c|c|c|c|c|}
\hline Konstruk & Indikator & Cross Loading & $\begin{array}{c}\text { Composite Reliability } \\
(\mathrm{CR})\end{array}$ & $\begin{array}{c}\text { Average Variance Extracted } \\
\text { (AVE) }\end{array}$ \\
\hline \multirow{3}{*}{ Kesadaran Merk } & $\mathrm{X}_{1.1}$ & 0.876 & \multirow{3}{*}{0.899} & \multirow[t]{3}{*}{ 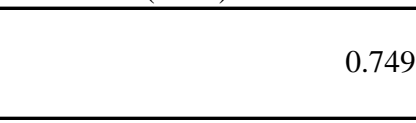 } \\
\hline & $\mathrm{X}_{1.2}$ & 0.885 & & \\
\hline & $\mathrm{X}_{1.3}$ & 0.833 & & \\
\hline \multirow{3}{*}{ Persepsi Kualitas } & $\mathrm{X}_{2.1}$ & 0.553 & \multirow{3}{*}{0.914} & \multirow{3}{*}{0.779} \\
\hline & $\mathrm{X}_{2.2}$ & 0.601 & & \\
\hline & $X_{2.3}$ & 0.634 & & \\
\hline \multirow{3}{*}{ Kesadaran Fashion } & $\mathrm{X}_{3.1}$ & 0.581 & \multirow{3}{*}{0.873} & \multirow{3}{*}{0.696} \\
\hline & $\mathrm{X}_{3.2}$ & 0.500 & & \\
\hline & $\mathrm{X}_{3.3}$ & 0.447 & & \\
\hline \multirow{3}{*}{ Kemauan Membeli } & $\mathrm{Y}_{1.1}$ & 0.592 & \multirow{3}{*}{0.923} & \multirow{3}{*}{0.800} \\
\hline & $\mathrm{Y}_{1.2}$ & 0.616 & & \\
\hline & $\mathrm{Y}_{1.3}$ & 0.556 & & \\
\hline \multirow{3}{*}{ Country of Origin } & $\overline{Z_{1.1}}$ & 0.470 & \multirow{3}{*}{0.912} & \multirow{3}{*}{0.777} \\
\hline & $\mathrm{Z}_{1.2}$ & 0.495 & & \\
\hline & $\mathrm{Z}_{1.3}$ & 0.544 & & \\
\hline \multirow{3}{*}{$\begin{array}{l}\text { Consumer } \\
\text { Ethnocentrism }\end{array}$} & $\mathrm{Z}_{2.1}$ & 0.392 & \multirow{3}{*}{0.848} & \multirow{3}{*}{0.650} \\
\hline & $\mathrm{Z}_{2.2}$ & 0.301 & & \\
\hline & $\mathrm{Z}_{23}$ & 0.301 & & \\
\hline
\end{tabular}

Sumber: hasil pengolahan data penelitian, 2016

indikator $\mathrm{X}_{3.3}$, dan hampir seluruh indikator untuk variabel country of origin dan consumer ethnocentrism, selain yang telah disebutkan setiap indikator memiliki nilai diatas rekomendasi. Selanjutnya untuk nilai CR dan AVE seluruh variabel penelitian ini memiliki nilai diatas rekomendasi. Sehingga bisa dikatakan validitas model ini cukup baik.

\section{Discriminant Validity}

Untuk mengevaluasi discriminant validity, suatu model disarankan untuk memastikan bahwa nilai akar AVE sebuah variabel laten harus lebih besar daripada nilai korelasi antar variabel laten yang lain (Fornell \& Larcker, 1981).

Tabel 4. Correlations of Constructs

\begin{tabular}{|c|c|c|c|c|c|c|}
\hline Konstruk & $\begin{array}{l}\text { Kesadaran } \\
\text { Merk }\end{array}$ & $\begin{array}{l}\text { Consumer } \\
\text { Ethnocentrism }\end{array}$ & $\begin{array}{l}\text { Country of } \\
\text { Origin }\end{array}$ & $\begin{array}{l}\text { Kesadaran } \\
\text { Fashion }\end{array}$ & $\begin{array}{l}\text { Perspesi } \\
\text { Kualitas }\end{array}$ & $\begin{array}{l}\text { Kemauan } \\
\text { Membeli }\end{array}$ \\
\hline Kesadaran Merk & 0.865 & & & & & \\
\hline $\begin{array}{l}\text { Consumer } \\
\text { Ethnocentrism }\end{array}$ & 0.413 & 0.806 & & & & \\
\hline Country of Origin & 0.570 & 0.473 & 0.881 & & & \\
\hline $\begin{array}{l}\text { Kesadaran } \\
\text { Fashion }\end{array}$ & 0.613 & 0.496 & 0.537 & 0.834 & & \\
\hline Perspesi Kualitas & 0.675 & 0.414 & 0.689 & 0.540 & 0.883 & \\
\hline Kemauan Membeli & 0.657 & 0.401 & 0.611 & 0.680 & 0.618 & 0.895 \\
\hline
\end{tabular}

Sumber: Hasil pengolahan data penelitian, 2016

Pada tabel hubungan antar konstruk nilai discriminant validity dari model penelitian ini bisa dianggap baik, dimana nilai diagonal pada tabel $(\sqrt{A V E})$ lebih tinggi nilainya dibandingkan dengan nilai korelasi antar variabel yang membentuk konstruk tersebut.

\section{Pengujian Hipotesis}

Pengujian hipotesis menggunakan program SmartPLS, hasil pengujian model 1 dilakukan dengan melihat nilai $t$-statistic dengan tingkat signifikansi 95 persen, informasi mengenai nilai original sample dan disajikan pada tabel path coefficient Model 1. 


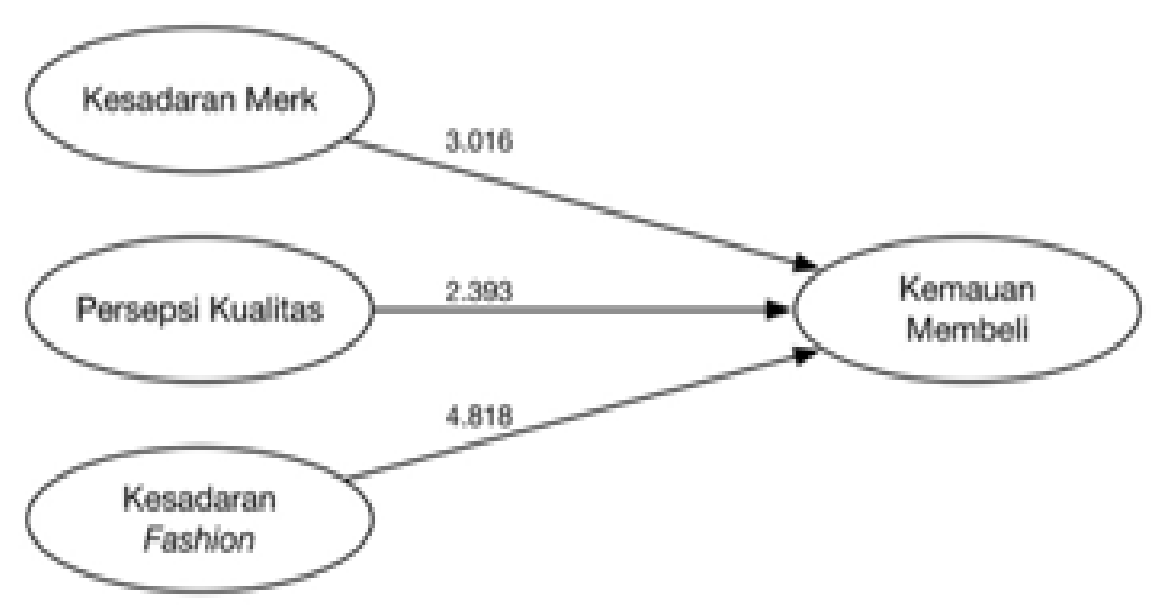

Gambar 2: Analisis Model 1

Tabel 5. Path Coefficient Model 1

\begin{tabular}{lll}
\hline & Original Sample & T Statistic \\
\hline Kesadaran Merk $\rightarrow$ Kemauan Membeli & 0.253 & 3.016 \\
\hline Persepsi Kualitas $\rightarrow$ Kemauan Membeli & 0.241 & 2.292 \\
\hline Kesadaran Fashion $\rightarrow$ Kemauan Membeli & 0.389 & 4.818
\end{tabular}

Sumber: Hasil pengolahan data penelitian, 2016

Berdasarkan pengujian hipotesis pada Tabel 5 dapat dijelaskan bahwa masing-masing kesadaran merk, persepsi kualitas, dan kesadaran fashion berpengaruh signifikan secara positif terhadap niat beli, ditunjukan dengan nilai $T$-statistic secara berurutan yaitu 3.016, 2.292, dan 4.818 yang semuanya memiliki nilai diatas 1.96 dan semua nilai original sample berada diatas 0.05. Berdasarkan perbandingan nilai tersebut maka hipotesis 1 , hipotesis 2, dan hipotesis 3 diterima. Kesimpulan dari pengujian hipotesis tersebut maka kesadaran merk, persepsi kualitas dan kesadaran fashion memiliki pengaruh signifikan dan secara positif terhadap kemauan membeli.

Setelah pengujian model 1 selanjutnya dilakukan pengujian model 2 dimana model ini meng implementasikan variabel country of origin dan consumer ethnocentrism sebagai variabel moderator dari interaksi variabel-variabel yang telah diuji pada model 1. Berikut Tabel 6 yang menyajikan informasi perhitungan koefisien jalur dengan 2 variabel sebagai moderator.

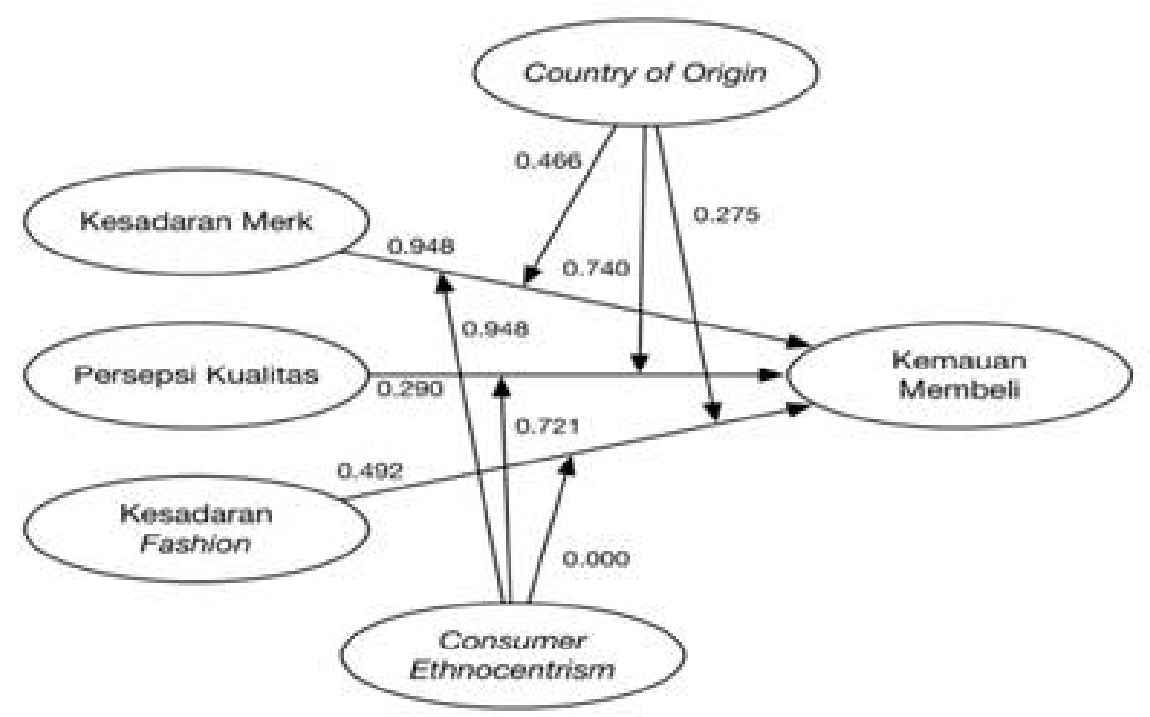

Gambar 3: Analisis Model 2 
Tabel 6. Path Coefficient Model 2

\begin{tabular}{lll}
\hline & Original Sample & T Statistic \\
\hline Kesadaran Merk * Consumer Ethnocentrism $\rightarrow$ Kemauan Membeli & -0.712 & 0.948 \\
\hline Persepsi Kualitas * Consumer Ethnocentrism $\rightarrow$ Kemauan Membeli & 0.574 & 0.721 \\
\hline Kesadaran Fashion * Consumer Ethnocentrism $\rightarrow$ Kemauan Membeli & 0.000 & 0.000 \\
\hline Kesadaran Merk * Country of Origin $\rightarrow$ Kemauan Membeli & 0.416 & 0.466 \\
\hline Persepsi Kualitas * Country of Origin $\rightarrow$ Kemauan Membeli & -0.570 & 0.740 \\
\hline Kesadaran Fashion * Country of Origin $\rightarrow$ Kemauan Membeli & 0.188 & 0.275 \\
\hline
\end{tabular}

Sumber: Hasil pengolahan data penelitian, 2016

Tabel 6 menunjukkan pengujian hipotesis dengan model 2 dengan variabel moderasi consumer ethnocentrism akan melihat bagaimana hubungan masing-masing kesadaran merk, persepsi kualitas, dan kesadaran fashion terhadap kemauan membeli. Pada hubungan kesadaran merk dengan kemauan membeli, moderasi consumer ethnocentrism menghasilkan nilai t-statistic sebesar 0.948 yang lebih kecil daripada t-tabel yaitu 1.96 artinya consumer ethnocentrism tidak mampu memoderasi hubungan antara kesadaran merk dengan kemauan membeli produk dari retail fashion global. Kemudian pada hubungan persepsi kualitas dengan kemauan membeli, uji moderasi consumer ethnocentrism menghasilkan nilai t-statistic 0.721 yang berada dibawah nilai t-tabel 1.96 yang berarti consumer ethnocentrism bukan moderator variabel persepsi kualitas dengan kemauan membeli produk fashion retail global. Terakhir adalah hubungan antara kesadaran fashion terhadap kemauan membeli yang dimoderasi consumer ethnocentrism, uji ini menghasilkan nilai t-statistic 0.000 yang lebih kecil dari nilai t-tabel yaitu 1.96 yang berarti pada produk situasi pembelian fashion dari retail global consumer ethnocentrism tidak mampu memoderasi hubungan antara kesadaran fashion dengan kemauan membeli.

Pengujian hipotesis dengan menggunakan country of origin sebagai moderator ditunjukan bahwa kesadaran merk ketika hubungannya dengan kemauan membeli dimoderasi oleh country of origin menghasilkan t-statistic 0.466 yang nilainya lebih kecil daripada t-tabel yaitu 1.96. dapat disimpulkan bahwa country of origin tidak mampu memoderasi hubungan antara kesadaran merk dengan kemauan membeli untuk produk retail fashion global. Hubungan antara persepsi kualitas dengan kemauan membeli ketika dimoderasi oleh country of origin menghasilkan nilai t-statistik sebesar 0.740 yang lebih kecil dibandingkan dengan nilai t-tabel 1.96. Artinya country of origin tidak mampu memoderasi hubungan antara persepsi kualitas dengan kemauan membeli untuk produk retail fashion global. Terakhir adalah hubungan antara kesadaran fashion dengan kemauan membeli yang dimoderasi country of origin. Nilai t-statistic yang dihasilkan dari uji ini adalah sebesar 0.275 yang lebih kecil dibandingkan nilai t-tabel yaitu 1.96 artinya country of origin tidak mampu memoderasi kesadaran fashion dengan kemauan membeli untuk produk fashion retail global.

Uji moderasi country of origin terhadap tiga variabel bebas dan hubungannya terhadap kemauan membeli dapat disimpulkan bahwa country of origin bukan moderator yang dapat mempengaruhi hubungan kesadaran merk, persepsi kualitas, dan kesadaran fashion terhadap kemauan membeli untuk produk fashion, sedangkan untuk consumer ethnocentrism dari tiga uji moderasi diatas maka dapat disimpulkan bahwa consumer ethnocentrism bukanlah variabel moderator untuk kemauan membeli suatu produk dari retail fashion global yang berkaitan dengan kesadaran merk, persepsi kualitas, dan kesadaran fashion ini berarti dapat disimpulkan bahwa hipotesis 4 dan hipotesis 5 ditolak.

\section{Pembahasan \\ Hubungan Kesadaran Merk Terhadap Kemauan Membeli}

Berdasarkan pengujian hipotesis pertama dalam studi ini menunjukan bahwa kesadaran merk memiliki pengaruh yang positif dan signifikan terhadap kemauan membeli. Hasil dari pengujian hipotesis ini mengkonfirmasi penelitian dari (Alden et al., 1999; Boguslaw, 2015; Chiu \& Ho, 2015; Kim et al., 2008; H. Wang et al., 2008) dimana seorang individu atau konsumen memandang suatu merk terutama yang berskala global merupakan suatu nilai superior sehingga merupakan salah satu faktor pendorong niat membeli. Maka apabila kesadaran merk tertentu yang ada pada benak konsumen semakin tinggi akan semakin tinggi pula dorongan kemauan membeli konsumen terhadap produk dengan merk tersebut.

\section{Hubungan Persepsi Kualitas Terhadap Kemauan Membeli}

Hasil pengujian hipotesis kedua pada penelitian ini ditunjukan bahwa persepsi kualitas memilik 
pengaruh yang positif dan signifikan terhadap kemauan membeli. Hasil dari uji hipotesis ini sejalan dengan temuan dari (González-Benito \& MartosPartal, 2014) yang menyatakan bahwa persepsi kualitas adalah faktor pembeda yang memberikan alasan kepada konsumen dalam proses penentuan keputusan pembelian. Terlebih dengan adanya faktor harga yang dianggap lebih mahal maka konsumen mengasosiasikan harga kepada kualitas (Blattberg \& Wisniewski, 1989). Pemaparan tersebut sangat sesuai degan situasi produk dari retail fashion global di pasar Negara berkembang, strategi penetapan harga yang diatas harga pesaing umumnya diasosiasikan dengan kualitas lebih baik sehingga jika konsumen memiliki persepsi kualitas semakin tinggi akan semakin tinggi pula kemauan membeli produk fashion oleh konsumen.

\section{Hubungan Kesadaran Fashion Terhadap Kemauan Membeli}

Berdasarkan pengujian hipotesis ketiga pada studi ini menunjukan bahwa kesadaran fashion berpengaruh positif dan signifikan terhadap kemauan membeli produk fashion dari ritel global. Hal ini berkaitan dengan perilaku materialistik yang dimiliki oleh individu dimana pandangan bahwa citra diri dapat diproyeksikan melalui pakaian yang dikenakan (O'Cass, 2000) sehingga hasil analisa dari hipotesis ketiga ini sejalan dengan kesimpulan yang telah dipublikaskan oleh (Belleau et al., 2008; Joung, 2013) dimana semakin tinggi kesadaran fashion seseorang akan semakin tinggi juga kemauan membeli produk fashion dari retail global.

\section{Efek Moderasi Country of Origin}

Hasil pengujian dampak moderasi country of origin terhadap masing-masing variabel kesadaran merk, persepsi kualitas, dan kesadaran fashion hubungannya dengan kemauan membeli dinyatakan bahwa variabel country of origin tidak mampu memoderasi hubungan antara tiga variabel eksogen dengan satu variabel endogen. Ketidakmampuan country of origin sebagai moderator dapat diuraikan dengan mengacu kepada hasil studi dari (Ahmed \& d'Astous, 2004) yang menyatakan bahwa ketika suatu produk membawa merk dengan equitas tinggi maka petunjuk country of origin sebagai faktor evaluasi suatu produk oleh konsumen menjadi sangat lemah, merk dijadikan faktor dominan yang menentukan keputusan pembelian. Berikutnya hasil studi dari (Souiden, Pons, \& Mayrand, 2011) yang menyimpulkan bahwa untuk produk yang memiliki kompleksitas rendah maka peran country of origin sebagai faktor evaluasi produk oleh konsumen akan semakin berkurang.

Secara keseluruhan citra suatu Negara sebagai lokasi manufaktir produk fashion tidak mampu mempengaruhi hubungan antara kesadaran merk, persepsi kualitas, dan kesadaran fashion terhadap kemauan membeli. Hasil ini sejalan fakta dengan semakin tingginya jumlah eksport hasil industry textile dari Negara ekonomi berkembang, yang merupakan dampak dari kegiatan produksi oleh perusahaan global dengan ekuitas merk tinggi.

\section{Efek Moderasi Consumer Ethnoentrism}

Berdasarkan hasil uji hipotesis yang berkaitan dengan consumer ethnocentrism sebagai moderator dinyatakan pada studi ini consumer ethnocentrism tidak mampu mempengaruhi interaksi antara kesadaran merk, persepsi kualitas, dan kesadaran fashion terhadap kemauan membeli. Hasil ini beresonansi dengan studi (Acharya \& Elliott, 2003) yang menyatakan jika semakin tinggi keterlibatan individu terhadap produk yang akan dibeli maka dampak dari sikap ethnocentrism akan semakin kecil, dikarenakan konsumen akan semakin objektif dalam penilaian untuk mengurangi resiko pembelian.

Didukung juga oleh hasil studi dari (C. L. Wang \& Chen, 2004) yang berkesimpulan bahwa konsumen pada ekonomi berkembang seperti Indonesia, dampak dari sikap ethnocentrism sangat dipengaruhi oleh conspicuous consumption yaitu konsumsi yang bertujuan untuk memperlihatkan kekuatan ekonomi. Pada situasi ini merk terkenal dan gaya (style) yang berasal dari negara ekonomi maju lebih dominan menjadi penentu keputusan pembelian dibandingkan sikap ethnocentrism.

Situasi ini sangat sesuai penerapannya pada industri retail fashion, dimana produknya sendiri merupakan hybrid karena buramnya asal usul produk fashion, akan tetapi yang tetap menjadi acuan adalah 'gaya' atau style yang dibawa oleh merk fashion tersebut harus jelas berasal dari Negara yang memiliki kultur fashion yang tinggi. Dengan kata lain, konsumen hampir tidak memperdulikan label 'made in' dan sering mengabaikan asal merk fashion, namun style produk fashion harus berasal dari tempat utama cita rasa gaya (Lim \& O'Cass, 2001).

\section{SIMPULAN DAN SARAN}

Pada penelitian ini responden menganggap produk fashion dalam artian pakaian dan segala akesoris untuk mendukung penampilan adalah produk yang memiliki keterlibatan dalam pembelian 
(high involvement) yang tinggi karena berkaitan dengan cita rasa dan penampilan, akan tetapi disaat yang bersamaan produk fashion bukanlah produk yang kompleks, artinya secara umum tidak membutuhkan tingkat pengetahuan tertentu untuk memiliki pemahaman dalam menentukan pilihan produk, sehingga petunjuk utama dalam menentukan pilihan produk fashion adalah merk, persepsi akan kualitas yang diasosiasikan erat dengan merk itu sendiri, dan kesadaran akan fashion yang melekat pada individu. Kesimpulannya kemauan membeli produk fashion dipengaruhi oleh kesadaran merk, persepsi kualitas, dan kesadaran fashion, dengan semakin tinggi tingkat ketiga aspek tersebut maka akan meningkatkan kemauan membeli produk fashion.

Pada penelitian ini peran country origin dan consumer ethnocentrism tidak mampu mempengaruhi kekuatan hubungan antara kesadaran merk, persepsi kualitas, dan kesadaran fashion kepada kemauan membeli. Hal ini disebabkan karena produk fashion terutama yang memiliki skala operasi global, merupakan daya tarik utama untuk produk fashion terlebih kepada konsumen dengan usia antara 18 tahun hingga 24 tahun yang sangat memprioritaskan citra diri melalui fashion serta terbuka berekspresi terhadap kultur baru. Selanjutnya produk fashion merupakan produk yang memiliki muatan kerumitan penciptaan yang sangat rendah, sehingga kualitas dan performa produk tidak dihubungkan kepada bias akan lokasi produksi dan rasa etnhnocentrism yang ada pada konsumen, sehingga menjadi tidak relevan terutama produk fashion dengan daya tarik global. Melalui studi ini jelas bahwa dampak dari konsep ethnocentrism dan country of origin merupakan suatu konsep multifacet artinya memiliki dampak atau pengaruh yang tidak pernah konsisten tergantung dengan kaitannya dengan beberapa konsep diantaranya jenis produk, negara berkembang atau maju, sifat pembelian, pengetahuan konsumen, dan lainnya (P. Sharma, 2010).

\section{Rekomendasi penelitian selanjutnya}

Studi ini berkontribusi kepada penelitian pada area country of origin dan consumer ethnocentrism dalam beberapa unsur, pertama, desain penelitian ini mengkombinasikan model yang telah dikembangkan oleh (S. a. Ahmed \& D'Astous, 2008) yang memakai country of origin sebagai pusat modelnya dan kerangka konsep dari (S. Sharma et al., 1995) yang mengimplementasikan ethnocentrism kepada perilaku konsumen, kemudian aspek pembeda pada studi ini adalah kombinasi citra negara yang kuat diwakili dari asal merk dan citra negara lemah dimunculkan oleh lokasi produksi dan dipadukan dengan sikap spesifik terhadap negara yang dimiliki oleh konsumen dinyatakan dengan ethnocentrism. Penggabungan faset seperti merk dengan skala global, lokasi produksi dengan citra lemah dan sikap ethnocentrism pada konsumen negara berkembang membuat hasil dari penelitian ini memiliki kekuatan menjelaskan yang sangat kuat terutama pada jangkauan produk dengan multiple country of origin yang hingga saat ini masih tahap awal di dunia akademis. Kedua, studi ini menggunakan produk yang sederhana (kompleksitas rendah) namun tinggi keterlibatan pembelian dan lekat dengan pencitraan seseorang kontradiksi unik memberikan sudut pandang yang baru utamanya pada penelitian sejenis yang menggunakan produk rumit dan tinggi konten teknologi dan aspek utama yang menentukan bagi konsumen adalah value.

Dalam penelitian ini penulis juga menemukan beberapa kelemahan yang bisa dikembangkan melalui penelitian kedepan, pertama, pada studi ini antara citra country of origin (citra yang berkaitan dengan tingkat industrialisasi) dan citra negara secara umum dianggap satu kesatuan, yang pada realitanya merupakan dua hal yang berlainan dan sangat baik untuk penelitian selanjutnya memisahkan citra country of origin dengan citra negara menjadi dua variabel berbeda. Kedua, penelitian ini menggunakan produk yang tidak rumit, memiliki resiko pembelian rendah, namun high involvement ini menyebabkan bias negatif akibat citra country of origin dan ethnocentrism berkurang signifikan, sehingga sangat baik untuk penelitian selanjutnya yang menggunakan produk dengan karakteristik berlawanan dengan studi ini yaitu high involvement product, resiko pembelian tinggi, kompleksitas produk tinggi, sehingga citra country of origin menjadi lebih kuat pengaruhnya terhadap evaluasi produk oleh konsumen.

\section{REFERENSI}

Acharya, C., \& Elliott, G. (2003). Consumer ethnocentrism, perceived product quality and choice-An empirical investigation. Journal of International Consumer Marketing, 15(4), 87-115.

Ahmed, S. a., \& d'Astous, A. (2004). Perceptions of countries as producers of consumer goods: A T-shirt study in China. Journal of Fashion Marketing and Management, 8(2), 187-200. https://doi.org/10.1108/13612020410537889 
Ahmed, S. a., \& D'Astous, A. (2008). Antecedents, moderators and dimensions of country-of-origin evaluations. International Marketing Review, 25(1), 75-106. https://doi.org/10.1108/ 02651330810851890

Ahmed, S. A., d'Astous, A., \& Champagne, C. (2005). Country images of technological products in Taiwannull. Asia Pacific Journal of Marketing and Logistics, 17(2), 44-70. https://doi.org/10.1108/13555850510672331

Ahmed, Z. U., Johnson, J. P., Yang, X., Fatt, C. K., Teng, H. S., \& Boon, L. C. (2004). Does country of origin matter for low involvement products? International Marketing Review, 21(1), 102-120. https://doi.org/10.1108/ 02651330410522925

Alden, D. L., Steenkamp, J.-B. E. M., \& Batra, R. (1999). Brand Positioning Through Advertising in Asia, North America, and Europe: The Role of Global Consumer Culture. The Journal of Marketing, 63(1), 75-87. https://doi.org/ $10.2307 / 1252002$

Anholt, S. (2005). Anholt nation brands index: How does the world see America? Journal of Advertising Research, 45, 296-304. https:// doi.org/10.1017/S0021849905050336

Bakewell, C., Mitchell, V.-W., \& Rothwell, M. (2006). UK Generation Y male fashion consciousness. Journal of Fashion Marketing and Management, 10(2), 169-180. Retrieved from http://www.emeraldinsight.com/ 10.1108/13612020610667487

Barclay, D., Higgins, C., \& Thompson, R. (1995). The Partial Least Squares (PLS) approach to causal modeling: personal computer adoption and use as an illustration. Technology Studies, 2(2), 284-324.

Baughn, C. C., \& Yaprak, A. (1996). Economic Nationalism: Conceptual and Empirical Development. Political Psychology, 17(4), 759-778. https://doi.org/10.2307/3792137

Bawa, A. (2004). Consumer Ethnocentrism: CETSCALE Validation and Measurement of Extent. Vikalpa: The Journal for Decision Makers, 29(3), 43-57. Retrieved from http:// search.ebscohost.com/login.aspx?direct=true\& $\mathrm{db}=$ buh\&AN $=14830682 \&$ site $=$ ehost-live

Belleau, B., Haney, R. M., Summers, T., Xu, Y., \& Garrison, B. (2008). Affluent female consumers and fashion involvement. International Journal of Fashion Design, Technology and Education, 1(3), 103-112. https://doi.org/ $10.1080 / 17543260802425346$
Bhagwati, J. N. (2007). In Defense of Globalization/ : With a New Afterword. Oxford University Press, USA.

Blattberg, R. C., \& Wisniewski, K. J. (1989). PriceInduced Patterns of Competition. Marketing Science, 8(4), 291-309. https://doi.org/10.1287/ mksc.8.4.291

Boguslaw, S. (2015). Predicting consumers' purchase intention towards luxury fashion brands by applying several personality traits. University of Twente.

Cattin, P., Jolibert, A., \& Colleen, L. (1982). A Cross-Cultural Study of "Made in" Concepts. Journal of International Business Studies, 13(3), 131-141.

Chiou, J., \& Chuang, M. (2005). Antecedents of Taiwanese Adolescents ' Purchase Intention Toward the ... The Journal of Social Psychology, 145(3), 317-32.

Chiu, S. Y., \& Ho, J. S. Y. (2015). Local vs. Global Brands: Country-of-Origin's Effect on Consumer-based Brand Equity among StatusSeekers. Journal of Economics and Behavioral Studies (JEBS)2, 7(3), 6-13.

Çifci, S., Ekinci, Y., Whyatt, G, Japutra, A., Molinillo, S., \& Siala, H. (2016). A cross validation of Consumer-Based Brand Equity models: Driving customer equity in retail brands. Journal of Business Research, 69(9), 3740-3747.

De Chernatony, L., McDonald, M., \& Wallace, E. (2010). Creating Powerful Brands. Butterworth-Heinemann.

Dodds, W. B., Monroe, K. B., \& Grewal, D. (1991). Effects of Price, Brand, and Store Information on Buyers' Product Evaluations. Journal of Marketing Research, 28(3), 307. https:// doi.org/10.2307/3172866

E M Steenkamp, J.-B., Batra, R., \& Alden, D. L. (2003). How perceived brand globalness creates brand value. Journal of International Business Studies, 34(1), 53-65. https://doi.org/ 10.1057/palgrave.jibs. 8400002

Feldwick, P. (1996). Do we really need /'Brand Equity/'? J Brand Manag, 4(1), 9-28.

Fornell, C., \& Larcker, D. F. (1981). Structural equation models with unobservable variables and measurement error: Algebra and statistics. Journal of Marketing Research, 382-388.

Ghauri, P. N., \& Cateora, P. R. (2014). International Marketing. McGraw-Hill Education.

Goldsmith, R. E., Flynn, L. R., \& Clark, R. a. (2012). Materialistic, brand engaged and status consuming consumers and clothing behaviors. 
Journal of Fashion Marketing and Management, 16(1), 102-119. https://doi.org/ $10.1108 / 13612021211203050$

González-Benito, Ó., \& Martos-Partal, M. (2014). Price sensitivity versus perceived quality: moderating effects of retailer positioning on private label consumption. Journal of Business Economics and Management, 15(5), 935-950.

Hair Jr, J. F., Hult, G. T. M., Ringle, C., \& Sarstedt, M. (2016). A primer on partial least squares structural equation modeling (PLS-SEM). Sage Publications.

Holton, R. (2000). Globalization's Cultural Consequences. The Annals of the American Academy of Political and Social Science, 570, 140-152.

Hsieh, M.-H., Shan-Ling, P., Setiono, R., Pan, S.L., Setiono, R., Shan-Ling, P., ... Setiono, R. (2004). Product-, Corporate-, and CountryImage Dimensions and Purchase Behavior: A Multicountry Analysis. Journal of the Academy of Marketing Science, 32(3), 251270. https://doi.org/10.1177/0092070304264262

Hu, X., Li, L., Xie, C., \& Zhou, J. (2008). The effects of country of origin on Chinese consumers' wine purchasing behaviour. Journal of Technology Management in China, 3(3), 292-306. https:/ /doi.org/10.1108/17468770810916195

Johnson, T., \& Attmann, J. (2009). Compulsive buying in a product specific context: clothing. Journal of Fashion Marketing and Management, 13(3), 394-405. https://doi.org/ 10.1108/13612020910974519

Joung, H.-M. (2013). Materialism and clothing postpurchase behaviors. Journal of Consumer Marketing, 30(6), 530-537. https://doi.org/ 10.1108/JCM-08-2013-0666

Jung, H. J., Lee, Y., \& Kim, H. (2014). Impacts of country images on luxury fashion brand/ : facilitating with the brand resonance model, 18(2), 187-205. https://doi.org/10.1108/JFMM10-2013-0113

Kamal, S., Chu, S.-C., \& Pedram, M. (2013). Materialism, attitudes, and social media usage and their impact on purchase intention of luxury fashion goods among American and Arab young generations. Journal of Interactive Advertising, 13(1), 27-40.

Kim, D. J., Ferrin, D. L., \& Rao, H. R. (2008). A trust-based consumer decision-making model in electronic commerce: The role of trust, perceived risk, and their antecedents. Decision Support Systems, 44(2), 544-564. https:// doi.org/http://dx.doi.org/10.1016/ j.dss.2007.07.001

Kinra, N. (2006). The Effect of Country of origin on Foreign Brand Names in The Indian Market. Marketing Intelligence \& Planning, 24(1), 15-30. https://doi.org/10.1108/ 02634500610641534

Kucukemiroglu, O. (1999). Market segmentation by using consumer lifestyle dimensions and ethnocentrism: An empirical study. European Journal of Marketing, 33(5/6), 470-487. https://doi.org/10.1108/03090569910262053

Lim, K., \& O'Cass, A. (2001). Consumer brand classifications: an assessment of culture-oforigin versus country-of-origin. Journal of Product \& Brand Management, 10(2), 120136.

Lumpkin, J. R., Crawford, J. C., \& Kim, G. (1985). Perceived Risk as a Factor in Buying Foreign Clothes/ : Implications for Marketing Strategy. International Journal of Advertising: The Review of Marketing Communications, 4(2), 157-171.

Lysonski, S. (2014). Receptivity of young Chinese to American and global brands: psychological underpinnings. Journal of Consumer Marketing, 31(4), 250-262.

Malhotra, N. K., Birks, D. F., \& Wills, P. (2012). Marketing Research/ : An Applied Approach. Marketing Research.

Nagashima, A. (1977). A Comparative "Made in" Product Image Survey among Japanese Businessmen. Journal of Marketing, 41(3), 95-100. https://doi.org/10.2307/1250943

O'Cass, a. (2000). An assessment of consumers product, purchase decision, advertising and consumption involvement in fashion clothing. Journal of Economic Psychology, 21(5), 545-576. https://doi.org/10.1016/S01674870(00)00018-0

Pappu, R., Quester, P. G., \& Cooksey, R. W. (2005). Consumer-based brand equity: improving the measurement-empirical evidence. Journal of Product \& Brand Management, 14(3), 143154. https://doi.org/10.1108/10610420510601012

Rashid, M. S. (2016). Weakening the Effect of Unfavorable Country of Origin: A Process- and Parameter-Associated Theoretical Framework. Journal of Global Marketing, O(0), 1-12. https://doi.org/10.1080/08911762.2016.1226450

Richins, M. L., \& Dawson, S. (1992). A Consumer Values Orientation for Materialism and Its Measurement: Scale Development and 
Validation. Journal of Consumer Research, 19(3), 303. https://doi.org/10.1086/209304

Roth, M. S., \& Romeo, J. B. (1992). Matching Product Category and Country Image Perceptions: A Framework for Managing Country-of-Origin Effects. Journal of International Business Studies, 23(3), 477.

Sharma, P. (2010). Country of Origin Effects in Developed and Emerging Markets: Exploring the Contrasting Roles of Materialism and Value Consciousness. Journal of International Business Studies, 42(2), 285-306. Retrieved from http://www.palgrave-journals.com/ doifinder/10.1057/jibs.2010.16

Sharma, P. (2015). Consumer ethnocentrism: Reconceptualization and cross-cultural validation. Journal of International Business Studies, 46(3), 381-389. https://doi.org/ 10.1057/jibs.2014.42

Sharma, S., Shimp, T. a., \& Shin, J. (1995). Consumer ethnocentrism: A test of antecedents and moderators. Journal of the Academy of Marketing Science, 23(1), 26-37. https:// doi.org/10.1007/BF02894609

Shimp, T. A., \& Sharma, S. (1987). Consumer Ethnocentrism: Construction and Validation of the CETSCALE. Journal of Marketing Research, 24(3), 280-289. Retrieved from http:/ /www.jstor.org/stable/3151638

Shirin, K., \& Kambiz, H. H. (2011). The effect of the country-of-origin image, product knowledge and product involvement on consumer purchase decisions. Chinese Business Review, 10(8), 601-615. Retrieved from http:// www.davidpublishing.com/davidpublishing/ Upfile/10/17/2011/2011101778898297.pdf\%5 Cnhttp://emedien. sub.uni-hamburg.de/hanEcon LitwithFullText/web.ebscohost.com/ehost/ detail?sid=1 ae 8 aa $44-$ c 9 ce- 4 cff- 9 b2f- 2 cafeaeb8108@sessionmgr4\& vid=1\&hid=18\& bdata $=\mathrm{JnNpd}$

Souiden, N., Pons, F., \& Mayrand, M.-E. (2011). Marketing High-tech Products in Emerging Markets: The Differential Impacts of Country Image and Country-of-origin's Image. Journal of Product \& Brand Management, 20(5), 12.

Thøgersen, J., Thøgersen, J., Pedersen, S., Pedersen, S., Paternoga, M., Paternoga, M., ... Aschemann-Witzel, J. (2017). How important is country-of-origin for organic food consumers? A review of the literature and suggestions for future research. British Food Journal, 119(3), 542-557.
Thomas, S. E., \& Wilson, P. R. (2013). Has Globalization Led to the Spread of Materialistic Values and High Consumption Cultures Enabled by Debt in Urban India? Asian Pacific Journal Of Marketing \& Management Review, 2(12), 55-64. Retrieved from http://www.i-scholar.in/ index.php/apjmmr/article/view/43856

Torelli, C. J. (2013). Globalization, Culture, and Branding: How to Leverage Cultural Equity for Building Iconic Brands in the Era of Globalization. Palgrave Macmillan. Retrieved from https://books.google.com.co/ books?id=2OOxAgAAQBAJ

Touzani, M., Fatma, S., \& Meriem, L. M. (2015). Country-of-origin and emerging countries: Revisiting a complex relationship. Qualitative Market Research, 18(1), 48-68. https://doi.org/ 10.1108/QMR-04-2012-0019

van Elteren, M. (2014). Reconceptualizing "Cultural Imperialism" in the Current Era of Globalization. In R. S. Fortner \& P. M. Fackler (Eds.), The Handbook of Media and Mass Communication Theory. Hoboken, NJ: John Wiley \& Sons, Inc. https://doi.org/10.1002/ 9781118591178.ch22

Wang, C. L., \& Chen, Z. X. (2004). Consumer ethnocentrism and willingness to buy domestic products in a developing country setting: testing moderating effects. Journal of Consumer Marketing, 21(6), 391-400. https://doi.org/ 10.1108/07363760410558663

Wang, H., Wei, Y., \& Yu, C. (2008). Global brand equity model: combining customer-based with product-market outcome approaches. Journal of Product \& Brand Management, 17(70632003), 305-316. https://doi.org/10.1108/ 10610420810896068

Wang, X., \& Yang, Z. (2008). Does Country of origin Matter in the Relationship Between Brand Personality and Purchase Intention in Emerging Economies? International Marketing Review, 25(4), 458-474.

Warren J. Bilkey, E. N. (1982). Country-of-Origin Effects on Product Evaluations. Journal of International Business Studies, 13(1), 89-99. Retrieved from http://www.jstor.org/stable/ 154256

Yoo, B., Donthu, N., \& Lee, S. (2000). An Examination of Selected Marketing Mix Elements and Brand Equity. Journal of the Academy of Marketing Science, 28(2), 195211. https://doi.org/10.1177/0092070300282002 